\title{
LEUKOKINETIC STUDIES. II. A METHOD FOR LABELING GRANULOCYTES IN VITRO WITH RADIOACTIVE DIISOPROPYLFLUOROPHOSPHATE $\left(\mathrm{DFP}^{32}\right)^{*}$
}

\author{
By A. M. MAUER, $\dagger$ J. W. ATHENS, HELEN ASHENBRUCKER, G. E. CARTWRIGHT \\ AND M. M. WINTROBE \\ (From the Department of Medicine, University of Utah College of Medicine, \\ Salt Lake City, Utah)
}

(Submitted for publication November 23, 1959; accepted May 26, 1960)

In a previous publication from this laboratory (1), radioactive diisopropylfluorophosphate $\left(\mathrm{DFP}^{32}\right)$, a potent and irreversible esterase inhibitor, was shown to be a suitable label for granulocytes. Evidence was presented that the label is firmly attached to granulocytes; it does not modify the viability of the cells, and the label is not reutilized when the cells are degraded. Experiments designed to determine whether or not elution of the label occurs failed to provide such evidence. More recent studies (2), carried out with tritiated DFP and autoradiography, have confirmed the observation that the label is attached to granulocytes and little, or not at all, to lymphocytes or to monocytes.

A method for labeling granulocytes in vivo with $\mathrm{DFP}^{32}$ was described in the previous publication (1). The purpose of this paper is to describe a method for labeling granulocytes in vitro, and to describe the manner in which granulocytes so labeled leave the circulation of normal subjects. Several preliminary reports of this work have been published $(3,4)$.

\section{MATERIAL AND METHODS}

Subjects. A total of 82 volunteers from the Utah State Prison was used in these studies. All of the subjects were normal, healthy males, 20 to 50 years of age, with normal leukocyte values. Each subject was used only once in the study. All of the studies were started between 8 and 10 a.m.

Method of labeling gramulocytes in vitro. Five hundred $\mathrm{ml}$ of blood was withdrawn from the subject into a sterile, plastic bag ${ }^{1}$ containing $67.5 \mathrm{ml}$ of ACD-A solu-

* This investigation was supported in part by research grants (C-2231 and CY-2349) from the National Cancer Institute and in part by a graduate training grant (2A5098) from the National Institute of Arthritis and Metabolic Diseases, Bethesda, Md.

$\dagger$ Aided by a Postdoctoral Fellowship from the American Cancer Society.

1 Pliapak, Abbott Laboratories, North Chicago, Ill. tion. ${ }^{2} \mathrm{DFP}^{32}$ was added to the blood in the bag in a concentration of $0.3 \mu \mathrm{g}$ per $\mathrm{ml}$ of whole blood and the contents were mixed gently. The blood was allowed to remain at room temperature for 1 hour with occasional gentle mixing. At the end of this time, a $20 \mathrm{ml}$ sample of blood was obtained from the bag and the remainder of the blood was infused into the subject over a 10 to 15 minute period.

Samples of blood, $20 \mathrm{ml}$ each, were withdrawn at 0,3 , $6,10,24$ and 30 hours after completion of the infusion. The methods for the isolation of the leukocytes from the blood samples and for determination of leukocyte radioactivity have been described previously (1).

Calculations. The percentage of cells infused which could be demonstrated in the circulation immediately after the infusion was calculated in the following manner. The specific activity (counts per minute per milligram leukocyte nitrogen) of the leukocytes in the bag was determined at the time of the infusion. From this determination, the volume of blood injected, and the calculated blood volume $(5,6)$, the expected counts per minute of the leukocytes in the circulation immediately after completion of the 15 minute infusion $\left(t_{0}\right)$ were calculated:

$\begin{gathered}\text { expected specific activ- } \\ \text { ity cells in blood at } t_{0}\end{gathered}=\frac{\begin{array}{c}\text { specific activity of cells in bag } \\ \times \text { volume of blood labeled }\end{array}}{\text { blood volume }}$

The specific activity of the cells in the blood immediately after the infusion $\left(t_{0}\right)$ was determined by extrapolation of the exponential granulocyte disappearance curve to the ordinate. The percentage of infused cells which was present in the circulation at $t_{0}$ was then calculated as follows:

$\frac{\text { determined specific activity of cells at } t_{0}}{\text { expected specific activity of cells at } t_{0}} \times 100$

$=$ percentage of infused cells present in the circulation at $t_{0}$.

The time for half of the labeled granulocytes to leave the blood $\left(\mathrm{T}_{\frac{1}{2}}\right)$ was determined by plotting the leukocyte radioactivities against time in hours on semilogarithmic paper.

Radiation dosage to the subjects. When $\mathrm{DFP}^{32}$ with a specific activity of $200 \mu \mathrm{c}$ per $\mathrm{mg}$ was used, a total of 30 $\mu \mathrm{c}$ of radioactivity was administered to each subject. The

2 Each $100 \mathrm{ml}$ contains $2.45 \mathrm{~g}$ of dextrose, $2.20 \mathrm{~g}$ of sodium citrate, and $0.73 \mathrm{~g}$ of citric acid. 


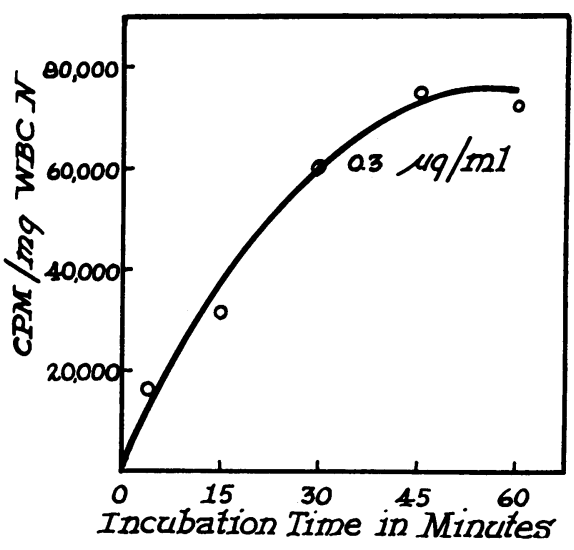

Fig. 1. UPtake of DFP ${ }^{32}$ By GRanUlocytes IN RELATION TO TIME:

compound was presumably bound firmly to erythrocytes, leukocytes, platelets and plasma proteins and, therefore, $30 \mu \mathrm{c}$ of isotope was distributed predominantly in about $5 \mathrm{~kg}$ of blood with very little radioactivity reaching the bone marrow or other tissues. In three subjects, in whom the urinary excretion of radioactivity was studied, 40 per cent of the administered radioactivity appeared in the urine within the first 8 hours after infusion of the labeled blood. Thereafter, the biological half-life of the radiophosphorus in the body was approximately 6 days. The effective half-life was calculated to be 4.4 days (7). With the nomogram of Bertinchamps and Cotzias (7), the infinite dose of radioactivity administered to blood was calculated to be about 860 millirads. This figure represents the maximum dose, since the above calculation of the biological half-life does not take into consideration the excretion of $\mathrm{DFP}^{32}$ through routes other than the kidneys.

Analysis of the DFP preparations. $\mathrm{DFP}^{32}$ was purchased from a commercial source ${ }^{3}$ as a dilute solution in sterile, anhydrous propylene glycol. The amount of $\mathrm{DFP}^{32}$ present in the solution was determined by the colorimetric method of Marsh and Neale (8) as modified by Wilcox and Neurath. 4

Nine different batches of $\mathrm{DFP}^{32}$ were used in these studies. The determined DFP concentrations were found to range from 15 to 100 per cent of the concentration stated by the manufacturer. The specific activities of the batches, at the time the material was used, ranged from 103 to $336 \mu \mathrm{c}$ per $\mathrm{mg}$.

\section{RESULTS}

Rate of uptake of DFP into leukocytes. To determine the period of incubation required to obtain optimal labeling of granulocytes, blood was

${ }^{8}$ Manning Research Laboratories, Waltham, Mass.

4 We are indebted to Dr. Hans Neurath, University of Washington, Seattle, Wash., for supplying us with this method. drawn into a plastic bag and incubated for 1 hour at room temperature with $0.3 \mu \mathrm{g}$ of $\mathrm{DFP}^{32}$ per ml of whole blood. The uptake of $\mathrm{DFP}^{32}$ into the leukocytes was maximal in about 45 minutes (Figure 1).

The following experiment was performed to determine whether or not any $\mathrm{DFP}^{32}$, which would be capable of labeling the leukocytes of the recipient, remained in the plasma after a 1 hour incubation period. From each of three subjects, $500 \mathrm{ml}$ of blood was withdrawn. The blood was incubated at room temperature for 1 hour with 0.3 $\mu \mathrm{g}$ of $\mathrm{DFP}^{32}$ per $\mathrm{ml}$. At the end of this time, the blood was centrifuged to remove all cells and the cell-free plasma was infused into the donors. No radioactivity could be demonstrated subsequently in either the leukocytes or the erythrocytes of the subjects.

Disappearance of labeled granulocytes from the circulation. The disappearance of labeled granulocytes from the blood was measured in 45 normal subjects. The labeled leukocytes left the circulation in an exponential fashion in all subjects. The leukocyte radioactivity disappearance curves obtained in four representative subjects are shown in Figure 2.

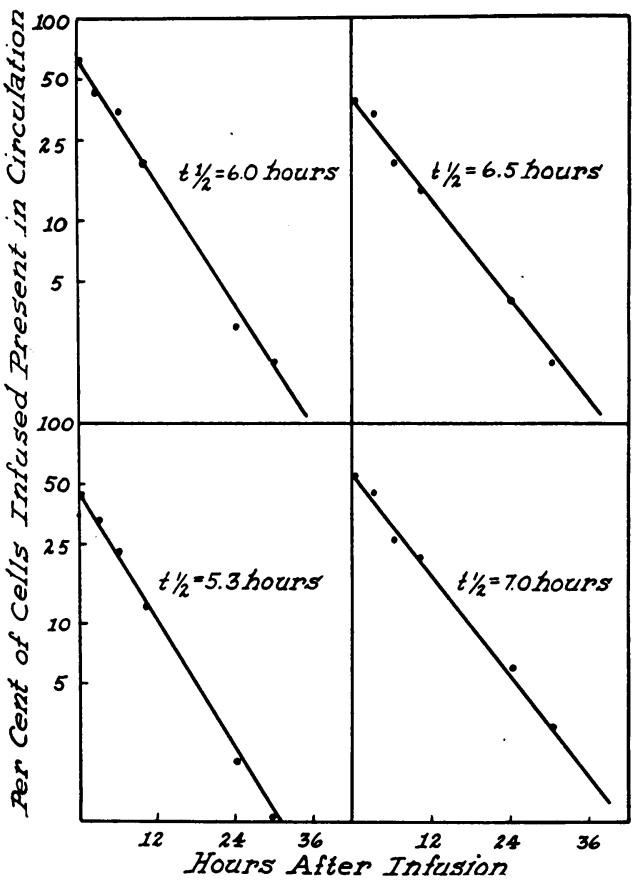

Fig. 2. Granulocyte radioactivity curves in FOUR REPRESENTATIVE SUBJECTS. 
TABLE I Influence of DFP concentration *

\begin{tabular}{|c|c|c|c|c|c|}
\hline \multirow{2}{*}{$\begin{array}{c}\text { Concen- } \\
\text { tration }\end{array}$} & \multirow{2}{*}{$\begin{array}{l}\text { No. of } \\
\text { subjects }\end{array}$} & \multicolumn{2}{|c|}{$\begin{array}{l}\text { Percentage of } \\
\text { infused cells } \\
\text { present at to }\end{array}$} & \multicolumn{2}{|r|}{$T_{1}$} \\
\hline & & Mean & Range & Mean & Range \\
\hline $\begin{array}{c}\mu g / m l \\
0.1 \\
0.2 \\
0.3 \\
0.7 \\
1.0\end{array}$ & $\begin{array}{l}4 \\
3 \\
8 \\
3 \\
3\end{array}$ & $\begin{array}{l}\% \\
33 \\
42 \\
49 \\
23 \\
42\end{array}$ & $\begin{array}{c}\% \\
27-39 \\
26-68 \\
27-62 \\
14-33 \\
29-57\end{array}$ & $\begin{array}{l}\text { hrs } \\
7.0 \\
7.5 \\
6.9 \\
7.2 \\
8.3\end{array}$ & $\begin{array}{c}\text { hrs } \\
6.0-8.0 \\
6.0-9.0 \\
5.5-8.0 \\
5.8-8.5 \\
7.0-9.0\end{array}$ \\
\hline
\end{tabular}

* Five hundred $\mathrm{ml}$ of blood was incubated in a plastic bag with ACD-A for 60 minutes at room temperature with the concentrations of $\mathrm{DFP}^{32}$ given above.

The mean $\mathrm{T}_{1}$ ( \pm one standard deviation) in the circulation was $6.6 \pm 1.4$ hours in the group of 45 normal male subjects, with a range of from 4.0 to 9.0 hours.

The percentage of infused cells which could be demonstrated in the circulation immediately after the infusion $\left(\mathrm{t}_{0}\right)$ averaged 49 , with a range of from 27 to 62 .

Influence of various factors on the disappearance rate of labeled granulocytes. The procedure was varied with respect to concentration of $\mathrm{DFP}^{32}$, temperature of incubation, volume of blood labeled, type of anticoagulant and container used, and the time of incubation. The influence of these procedural changes on the $T_{\frac{1}{1}}$ and on the percentage of infused cells which could be demonstrated in the circulation immediately after the infusion $\left(t_{0}\right)$ was studied.

Varying the concentration of the $\mathrm{DFP}^{32}$ between 0.1 and $1.0 \mu \mathrm{g}$ per $\mathrm{ml}$ had no influence on either the percentage of infused cells present in the circulation at $t_{0}$ or the $T_{1}$ (Table $I$ ). Incubating the blood at $1^{\circ}, 20^{\circ}$ and $37^{\circ} \mathrm{C}$ had no significant influence on these measurements (Table II). Likewise, labeling 100 or $250 \mathrm{ml}$ of blood rather than $500 \mathrm{ml}$ had no influence on the percentage of infused cells present at $t_{0}$ or on the $T_{1}$ (Table III). In single trials the use of heparin or sequestrene as an anticoagulant in place of ACD-A or the substitution of a siliconized glass container for the plastic container had no influence on these measurements.

Modifying the time of incubation from 15 minutes to 24 hours influenced significantly the percentage of infused cells present in the circulation at $t_{0}$ (Table IV). The proportion of the infused
TABLE II

Influence of incubation temperature *

\begin{tabular}{|c|c|c|c|c|c|}
\hline \multirow{2}{*}{$\begin{array}{l}\text { Temper- } \\
\text { ature }\end{array}$} & \multirow{2}{*}{$\begin{array}{l}\text { No. of } \\
\text { subjects }\end{array}$} & \multicolumn{2}{|c|}{$\begin{array}{l}\text { Percentage of } \\
\text { infused cells } \\
\text { present at to }\end{array}$} & \multicolumn{2}{|c|}{$T_{1}$} \\
\hline & & Mean & Range & Mean & Range \\
\hline $\begin{array}{r}37^{\circ} \mathrm{C} \\
20^{\circ} \mathrm{C} \\
1^{\circ} \mathrm{C}\end{array}$ & $\begin{array}{l}4 \\
8 \\
3\end{array}$ & $\begin{array}{l}\% \\
57 . \\
49 \\
44\end{array}$ & $\begin{array}{c}\% \\
38-68 \\
27-62 \\
31-54\end{array}$ & $\begin{array}{l}\text { hrs } \\
7.6 \\
6.9 \\
5.5\end{array}$ & $\begin{array}{c}\text { hrs } \\
6.0-8.7 \\
5.5-8.0 \\
4.4-6.1\end{array}$ \\
\hline
\end{tabular}

* Five hundred $\mathrm{ml}$ of blood was incubated in a plastic bag with ACD-A containing $0.3 \mu \mathrm{g}$ of DFP ${ }^{32}$ per $\mathrm{ml}$ for 60 minutes at the temperatures given above.

cells present in the circulation at $t_{0}$ decreased exponentially as the incubation period was prolonged (Figure 3). When blood was stored for more than 8 hours, less than 12 per cent of the infused cells was present in the circulation at $t_{0}$ and a disappearance curve could not be obtained.

No correlation was observed (correlation coefficient, -0.03 ) between the percentage of infused cells present in the circulation at $t_{0}$ and the $T_{1}$.

Transfusion of blood from normal subjects into normal recipients. Five hundred $\mathrm{ml}$ of blood was withdrawn from each of ten normal subjects. The blood was incubated for 60 minutes at room temperature with $0.3 \mu \mathrm{g}$ of $\mathrm{DFP}^{32}$ per $\mathrm{ml}$ and then transfused into a normal recipient other than the donor. All subjects were cross-matched for the major blood group and Rh type. None of the subjects had ever received a blood transfusion prior to the experiment.

In seven of the subjects the granulocytes disappeared in an exponential fashion. The $T_{1}$ values in this group (5.4 to 9 hours) were within normal limits for autogenous infusions. In one subject the experimental values were widely scattered, presumably due to technical errors, and a line

TABLE III

Influence of the volume of blood labeled *

\begin{tabular}{|c|c|c|c|c|c|}
\hline \multirow{2}{*}{$\begin{array}{l}\text { Volume } \\
\text { of blood } \\
\text { labeled }\end{array}$} & \multirow{2}{*}{$\begin{array}{l}\text { No. of } \\
\text { subjects }\end{array}$} & \multicolumn{2}{|c|}{$\begin{array}{l}\text { Percentage of } \\
\text { infused cells } \\
\text { present at to }\end{array}$} & \multicolumn{2}{|c|}{$T_{z}$} \\
\hline & & Mean & Range & Mean & Range \\
\hline$m l$ & & $\%$ & $\%$ & hrs & hrs \\
\hline 100 & 1 & 49 & & 7.3 & \\
\hline 250 & 3 & 43 & $37-46$ & 6.4 & $5.0-7.0$ \\
\hline 500 & 3 & 42 & $26-68$ & 7.5 & $6.0-9.0$ \\
\hline
\end{tabular}

* The volumes of blood given above were incubated in a plastic bag with ACD-A for 60 minutes at room temperature with $0.2 \mu \mathrm{g}$ of $\mathrm{DFP}^{32}$ per $\mathrm{ml}$ of blood. 
TABLE IV

Influence of incubation time*

\begin{tabular}{|c|c|c|c|c|c|}
\hline \multirow{2}{*}{$\begin{array}{l}\text { Time of } \\
\text { incuba- } \\
\text { tion }\end{array}$} & \multirow{2}{*}{$\begin{array}{l}\text { No. of } \\
\text { subjects }\end{array}$} & \multicolumn{2}{|c|}{$\begin{array}{l}\text { Percentage of } \\
\text { infused cells } \\
\text { present at } t_{0}\end{array}$} & \multicolumn{2}{|c|}{$T_{\frac{1}{2}}$} \\
\hline & & Mean & Range & Mean & Range \\
\hline hrs & & $\%$ & $\%$ & $h r s$ & hrs \\
\hline 0.25 & 3 & 47 & $26-81$ & 5.3 & $5.0-5.7$ \\
\hline 1 & $21 t$ & 41 & $14-72$ & 7.0 & $5.2-9.0$ \\
\hline 2 & 5 & 39 & $19-52$ & 9.4 & $7.5-12.0$ \\
\hline $8 f$ & 5 & 24 & $12-48$ & 9.0 & \\
\hline $16 t$ & 5 & 12 & $5-21$ & & \\
\hline $24 f$ & 4 & 7 & $5-9$ & & \\
\hline
\end{tabular}

* Five hundred $\mathrm{ml}$ of blood was incubated at room temperature in a plastic bag with ACD-A containing $0.3 \mu \mathrm{g}$ of DFP ${ }^{32}$ per ml of blood, with the exceptions noted.

$\dagger$ This group includes studies done with concentrations of $\mathrm{DFP}^{32}$ from 0.1 to $1.0 \mu \mathrm{g}$ per $\mathrm{ml}$.

$\ddagger$ Incubated for 1 hour at room temperature and at $5^{\circ} \mathrm{C}$ for the remainder of the incubation period.

could not be drawn through the points. In two of the subjects the granulocytes disappeared from the circulation in an exponential fashion but at an accelerated rate $\left(\mathrm{T}_{1}=2.5\right.$ and 1.2 hours $)$.

A transfusion of blood from a normal subject was given to a patient with hemophilia. This patient had received approximately 100 previous transfusions of plasma or whole blood. The $\mathrm{T}_{\frac{1}{2}}$ of the labeled cells in the circulation of the patient was 0.8 hour, in contrast to the normal mean of 6.6 hours. Twenty-two per cent of the transfused cells was present in the circulation of the patient at $t_{0}$.

\section{DISCUSSION}

This study was undertaken to determine the manner and rate of removal of normal granulocytes from the circulation of normal subjects. The technic described for labeling granulocytes in vitro has the advantage that only granulocytes circulating in the blood are labeled and, therefore, interpretation of the disappearance curves is more simple than interpretation of curves obtained following the intravenous administration of $\mathrm{DFP}^{32}$ (1).

Interpretation. With the method outlined, only about 50 per cent of the infused cells was present in the circulation at the completion of the infusion. Those cells which were not removed immediately disappeared from the circulation in an exponential fashion with a mean $\mathrm{T}_{1}$ of 6.6 hours. Thus, from a kinetic point of view, the labeled granulocytes appeared to behave as two distinct cell populations. Several explanations for this phenomenon may be offered.
The immediate disappearance from the circulation of about 50 per cent of the labeled cells could be due to rapid elution of the label, rapid removal of leukocytes damaged by the labeling procedure, or to distribution of the infused granulocytes in a larger pool of cells than that calculated from the blood volume and the granulocyte count.

As the result of studies previously reported (1) the possibility of elution seems remote but cannot be entirely excluded. However, if the label eluted in vivo, it might be expected that the percentage of labeled cells present at $t_{0}$ would decrease as the concentration of $\mathrm{DFP}^{32}$ was increased. Such was not found to be the case (Table I).

The possibility of damage to the cells during the labeling procedure deserves serious consideration since granulocytes removed from the body are highly susceptible to damage and it has been shown that damaged granulocytes are removed by the lungs, possibly the first time they pass through the circulation (9-13). In the studies reported here, a greater proportion of the infused granulocytes was missing from the circulation when blood was stored for 8 to 24 hours and then infused than when blood was incubated for an hour or less (Table IV and Figure 3) and infused. It appears, however, that rapid removal of labeled cells which have been damaged as a function of the time of incubation is not the sole reason for the immediate

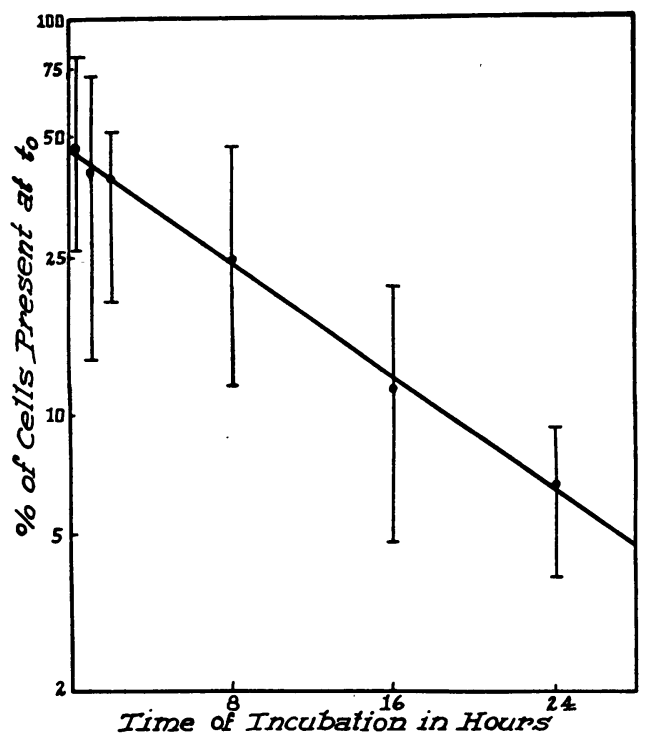

Fig. 3. The effect of time of incubation ON THE PERCENTAGE OF INFUSED CELLS PRESENT IN THE CIRCULATION AT TIME ZERO $\left(t_{0}\right)$. 
disappearance of about half of the labeled granulocytes. Extrapolation of the exponential curve (Figure 3 ) to the ordinate, i.e., zero incubation time and therefore presumably zero damage, suggests that 54 per cent $(100-46)$ of the infused cells was removed rapidly for a reason unrelated to the time of incubation.

The most plausible explanation for this rapid removal is that the labeled granulocytes are distributed in a pool of granulocytes larger than that calculated from the blood volume and the granulocyte count. Evidence in support of this concept will be presented in the next paper (14).

The exponential disappearance of labeled granulocytes from the circulation with a mean $T_{\frac{1}{3}}$ of 6.6 hours indicates that granulocytes leave the blood in a random fashion. That is, unlike erythrocytes, the disappearance of granulocytes from blood is unrelated to the time of entry of the cells into the circulation, and, by chance, a particular granulocyte may remain in the circulation only a few seconds or for an indefinitely long time. In this regard it is important that a correlation was not observed between the percentage of infused cells in the circulation at $t_{0}$ and the granulocyte disappearance rate $\left(T_{\frac{1}{2}}\right)$. This suggests that the $T_{\frac{1}{2}}$ is representative of the disappearance rate of the entire labeled population of cells, rather than that of a selected population as, for example, the youngest cells. The validity of the $T_{1}$ is further substantiated by the observation (3) that granulocytes labeled in vivo, without any handling, also disappeared from the circulation in a random fashion and at the same rate as do cells labeled in vitro and then returned to the circulation. The mean $\mathrm{T}_{1}$ of the cells labeled in vivo in 30 normal subjects was 6.4 hours; the mean $T_{1}$ for the cells labeled in vitro in the 45 normal subjects in this study was 6.6 hours. The difference between these mean values is not significant.

Application of the method. It is anticipated that this method will be useful in studying the granulocyte disappearance rate in leukemia and in other conditions. By the use of homologous transfusions in normal subjects, as illustrated by the ten preliminary studies reported herein, a reduction of the $T_{\frac{1}{2}}$ value may prove to be a highly sensitive method for detecting leukocyte incompatibilities and granulocyte blood groups. By a combination of autogenous infusion, transfusion of the patient's blood into a normal subject, and the transfusion of normal blood into the patient, it may become possible to differentiate granulocytopenias which are attributable to intracellular defects from those which may be produced by extracellular causes.

This method may also prove useful in the study of the preservation of granulocytes. Our studies clearly indicate that the longer granulocytes are stored, the more susceptible they become to immediate removal from the circulation. Ninety-one to 95 per cent of the granulocytes stored for 24 hours was removed immediately. Whether this is due to damage to the cells by the anticoagulant, by exposure to a foreign surface, by the depletion in the mixture of an essential nutrient, or by the accumulation in the stored blood of a product of cellular metabolism, is subject to experimental investigation.

\section{SUMMARY}

1. A method has been described for labeling granulocytes in vitro with radioactive diisopropylfluorophosphate $\left(\mathrm{DFP}^{32}\right)$. Briefly, the method is as follows: $500 \mathrm{ml}$ of blood is withdrawn into a plastic bag containing acid citrate dextrose solution and incubated at room temperature for 1 hour with $0.3 \mu \mathrm{g}$ of $\mathrm{DFP}^{32}$ per $\mathrm{ml}$ of blood. The blood containing the labeled granulocytes, erythrocytes and platelets is infused into the donor. At appropriate time intervals, $20-\mathrm{ml}$ samples of blood are withdrawn. The leukocytes are separated free of erythrocytes and platelets and the leukocyte radioactivity is determined.

2. Fifty-four per cent of the labeled granulocytes disappeared from the circulation during the infusion. The remainder of the granulocytes was removed from the circulation in an exponential fashion; the mean half-time in the circulation was $6.6 \pm 1.4$ hours in 45 normal male subjects.

3. The proportion of labeled cells infused which was present in the circulation at the end of the infusion was not influenced by the temperature of incubation, the concentration of $\mathrm{DFP}^{32}$, the volume of blood labeled, or the type of anticoagulant or container used, within the limits of the experiments performed. The proportion was influenced, however, by the time of incubation; the longer the blood was incubated, the smaller was the propor- 
tion of infused cells in the circulation immediately on completion of the infusion.

4. The time for the disappearance of one-half of the labeled granulocytes was not influenced by the proportion of infused cells which was demonstrable in the circulation at the end of the infusion, or by the time or temperature of incubation, the concentration of $\mathrm{DFP}^{32}$, the volume of blood labeled, or the type of anticoagulant or container used.

5. Ten normal male subjects were transfused with labeled blood from other normal subjects. In seven of the subjects, the granulocytes were removed at the normal rate. In two of the subjects, the granulocytes disappeared at an accelerated rate. In one subject, the experimental values were widely scattered and a line could not be drawn through the points.

6. The validity, limitations, interpretations and applications of this technic are discussed.

\section{ACKNOWLEDGMENTS}

The cooperation of Warden John Turner and Dr. William Knott of the Utah State Prison is very much appreciated. We are also grateful to those inmates of the Utah State Prison who made these studies possible. Mrs. Janet Anderson and Miss Dorothy Bunting provided valuable technical assistance. We are grateful to Dr. M. H. Kuizenga, Upjohn Company, Kalamazoo, Mich., for the supplies of heparin sodium; to Dr. D. M. Monroe, Dow Corning Corp., Los Angeles, Calif., for the silicone 4141; to Dr. G. M. Karus, Film Department, E. I. Du Pont de Nemours and Co., Wilmington, Del., for the Mylar; and to Dr. J. H. Brewer, Hynson, Westcott and Dunning, Baltimore, Md., for the supply of crude cobra venom.

\section{REFERENCES}

1. Athens, J. W., Mauer, A. M., Ashenbrucker, H., Cartwright, G. E., and Wintrobe, M. M. Leukokinetic studies. I. A method for labeling leukocytes with diisopropylfuorophosphate $\left(\mathrm{DFP}^{32}\right)$. Blood 1959, 14, 303.

2. Kurth, D., Athens, J. W., Cronkite, E. P., Cartwright, G. E., and Wintrobe, M. M. Unpublished data.
3. Mauer, A. M., Athens, J. W., Warner, H. R., Ashenbrucker, H., Cartwright, G. E., and Wintrobe, M. M. An analysis of leukocyte radioactivity curves obtained with radioactive diisopropylfluorophosphate $\left(\mathrm{DFP}^{32}\right)$ in The Kinetics of Cellular Proliferation, Frederick Stohlman, Jr., Ed. New York and London, Grune and Stratton, 1959, p. 231.

4. Mauer, A. M., Athens, J. W., Ashenbrucker, H., and Cartwright, G. E. In vitro labeling of granulocytes with DFP $^{32}$ (abstract). J. clin. Invest. 1959, 38, 1025.

5. Baker, R. J., Kozall, D. D., and Meyer, K. A. The use of surface area as a basis for establishing normal blood volume. Surg. Gynec. Obstet. 1957, 104, 183.

6. Peters, J. P., and Van Slyke, D. D. Quantitative Clinical Chemistry, 2nd ed. Baltimore, Williams and Wilkins, 1946, p. 29.

7. Bertinchamps, A. J., and Cotzias, G. C. Dosimetry in radioisotopes; a nomogram permits the estimation of the radiation dose delivered by 30 isotopes of biological interest. Science 1958, 128, 988.

8. Marsh, D. J., and Neale, E. A colorimetric method for the detection and determination of certain acid halide and acid anhydride compounds. Chem. and Ind. 1956, 22, 494.

9. Lanman, J. T., Bierman, H. R., and Byron, R. L., $\mathrm{Jr}$. Transfusion of leukemic leukocytes in man; hematologic and physiologic changes. Blood 1950, 5, 1099.

10. Bierman, H. R., Byron, R. L., Kelly, K. H., and Petrakis, N. L. The lung removal mechanism for leukocytes. Blood 1951, 6, 770.

11. Weisberger, A. S., Heinle, R. W., Storaasli, J. P., and Hannah, R. Transfusion of leukocytes labeled with radioactive phosphorus. J. clin. Invest. 1950, 29, 336.

12. Leahy, W. V., McNickle, T. F., and Smith, P. K. Fate of injected radiophosphorus-labeled leucocytes. Amer. J. Physiol. 1954, 179, 570.

13. Ambrus, C. M., and Ambrus, J. L. Regulation of the leukocyte level. Ann. N. Y. Acad. Sci. 1959, 77, 445.

14. Athens, J. W., Raab, S. O., Haab, O. P., Mauer, A. M., Ashenbrucker, H., Cartwright, G. E., and Wintrobe, M. M. Leukokinetic studies III. The distribution of granulocytes in the blood of normal subjects. In preparation. 